\title{
Pelaksanaan Pidana Pelatihan Kerja Terhadap Tindak Pidana Pencabulan oleh Anak di Balai Perlindungan dan Rehabilitasi Sosial Remaja
}

\author{
Ningrum Sulistio ${ }^{1}$, Trisno Raharjo ${ }^{2}$ \\ 1,2 Fakultas Hukum, Universitas Muhammadiyah Yogyakarta \\ Email : ${ }^{1}$ arumningrum812@gmail.com \\ 2trisnoraharjo@umy.ac.id
}

\section{Info Artikel}

\section{Kata Kunci :}

pelatihan kerja, sanksi pidana, tindak pidana pencabulan

\section{Perjalanan Artikel :}

Diterima : 25 Juli 2020

Direview : 27 Agustus 2020

Direvisi : 29 Agustus 2020

Dipublikasikan : Agustus 2020

DOI: 10.18196/ijclc.v1i2.9645

\begin{abstract}
Abstrak
Tindak pidana pencabulan merupakan bagian dari kejahatan terhadap kesusilaan, dimana perbuatan tersebut tidak saja terjadi pada orang dewasa tetapi juga terjadi pada anak. Undang-undang Nomor 11 tahun 2012 tentang Sistem Peradilan Pidana Anak menyebutkan sanksi pidana dalam Pasal 71 ayat (1) huruf c adalah pelatihan kerja. Penelitian ini bertujuan untuk mengetahui pelaksanaan pidana pelatihan kerja untuk anak pelaku tindak pidana pencabulan di Balai Perlindungan dan Rehalibitasi Sosial Remaja (BPRSR). Jenis penelitian ini termasuk dalam penelitian sosiologi hukum yang berkaitan dengan pelaksanaan pidana. Data primer yang diperoleh dari penelitian lapangan melalui wawancara kepada narasumber. Data sekunder diperoleh dari buku, dokumen dan hasil penelitian sebagai pelengkap data primer. Analisis data yang diperoleh menggunakan metode pendekatan kualitatif. Penelitan dilakukan di Balai perlindungan dan Rehalibitasi Sosial Remaja. Hasil penelitian menunjukkan bahwa pelaksanaan pelatihan kerja di BPRSR dilaksanakan dengan bentuk membersihkan masjid, ini disebabkan karena belum adanya peraturan pelaksana mengenai pidana pelatihan kerja tersebut. Pelaksanaan pelatihan kerja dengan membersihkan masjid belum bermanfaat untuk anak pencabulan dikarenakan membersihkan masjid adalah kegiatan sehari-hari dan bukan merupakan suatu keterampilan atau keahlian. Apabila Balai Perlindungan dan Rehalibitasi Sosial remaja dalam memberikan pelatihan kerja untuk anak yang melakukan tindak pidana pencabulan, pendidikan vokasional atau bimbingan ketrampilan akan bermanfaat sesuai dengan amanat Undangundang.
\end{abstract}

\section{Pendahuluan}

Tindak Pidana Pencabulan, ${ }^{1}$ merupakan suatu perbuatan yang tidak di kehendaki oleh masyarakat pada umumnya. Kejahatan ini dapat dilakukan baik orang dewasa maupun anak-anak. Setiap anak yang melakukan tindak pidana memerlukan pembinaan dan perlindungan dalam rangka menjamin pertumbuhan dan perkembangan fisik, mental dan sosial secara utuh, serasi, selaras, dan seimbang. ${ }^{2}$

\footnotetext{
${ }^{1}$ Tindak Pidana Pencabulan adalah segala macam wujud perbuatan, baik yang dilakukan pada diri sendiri maupun dilakukan pada orang lain mengenai dan yang berhubungan dengan alat kelamin atau bagian tubuh lainnya yang dapat merangsang nafsu seksual.

${ }^{2}$ Maidin Gultom, 2008, Perlindungan Hukum Terhadap Anak, Bandung, Refika Aditama, Hlm 2
} 
Tujuan dari sistem Peradilan Pidana dalam Undang-undang Nomor 11 Tahun 2012 tentang Sistem Peradilan Pidana Anak adalah untuk menjaga harkat dan martabat anak, di mana anak berhak mendapatkan perlindungan khusus, terutama perlindungan hukum dalam sistem peradilan. Selain itu, tujuan dari perlindungan anak adalah untuk menjamin terpenuhinya hak-hak anak agar dapat hidup, tumbuh dan berkembang dan berpatisipasi secara optimal sesuai dengan harkat dan martabat manusia serta mendapat perlindungan dari kekerasan dan diskriminasi. ${ }^{3}$ Sistem Peradilan Pidana Anak tidak hanya ditekankan pada penjatuhan sanksi pidana bagi anak pelaku tindak pidana, melainkan juga difokuskan pada pemikiran bahwa penjatuhan sanksi dimaksudkan sebagai sarana mewujudkan kesejahteraan anak pelaku tindak pidana tersebut.

Undang-undang Nomor 35 tahun 2014 tentang Perlindungan Anak menyebutkan bahwa anak yang melakukan suatu tindak pidana bukan tidak dapat dihukum, melainkan hukuman bagi anak sebisa mungkin tidak berat. Penangkapan, penahanan dan penjara hanya dilakukan apabila sesuai dengan hukum yang berlaku dan hanya dapat dilakukan sebagai upaya terakhir. ${ }^{4}$

Berdasarkan Putusan Pengadilan Negeri Bantul Nomor 5/Pid.Sus-Anak/2016/Pn.Btl Menyatakan Anak telah terbukti secara sah dan meyakinkan bersalah melakukan tindak pidana. Dengan Sengaja Membujuk Anak Melakukan Persetubuhan Dengannya. Menjatuhkan pidana penjara selama 4 (empat) tahun di LPKA (Lembina Pembinaan Khusus Anak) Wonosari dan menetapkan anak menjalani Pelatihan Kerja Sosial selama 3 (tiga) bulan di Balai Perlindungan Rehalibitasi Sosial Remaja, Daerah Istimewa Yogyakarta. Anak yang melakukan tindak pidana pencabulan diberikan pelatihan kerja sesuai dengan putusan Pengadilan yang dalam putusannya disebutkan dimana anak akan melaksanakan pidana pelatihan kerjanya.

Pelatihan kerja telah dikenal sejak di Undangkannya Undang-undang Nomor 3 Tahun 1997 tentang Pengadilan Anak yang saat ini diganti dengan Undang-undang Nomor 11 Tahun 2012 tentang Sistem Peradilan Pidana Anak namun sebagai pengganti pidana denda. Pelatihan Kerja dalam Undangundang Nomor 11 tahun 2012 tentang Sistem Peradilan Pidana Anak pada Pasal 71 ayat (1) huruf c jo Pasal 78 adalah pidana pokok yang dilaksanakan di lembaga yang melaksanakan pelatihan kerja yang sesuai dengan usia Anak dan dikenakan paling singkat 3 (tiga) bulan dan paling lama 1 (satu) tahun.

Penjelasan umum tentang latihan kerja dalam Pasal 24 ayat (1) Huruf b Undang-undang Nomor 3 Tahun 1997 tentang Pengadilan Anak bahwa Apabila Hakim berpendapat bahwa orang tua, wali, atau orang tua asuh tidak dapat memberikan pendidikan dan pembinaan yang lebih baik, maka Hakim dapat menetapkan anak tersebut ditempatkan di Lembaga Pemasyarakatan Anak untuk mengikuti pendidikan, pembinaan, dan latihan kerja. Latihan kerja dimaksudkan untuk memberikan bekal keterampilan kepada anak, misalnya dengan memberikan keterampilan mengenai pertukangan, pertanian, perbengkelan, tata rias, dan sebagainya sehingga setelah selesai menjalani tindakan dapat hidup mandiri.

Penerapan pidana pelatihan kerja terhadap anak, pada prinsipnya diharapkan dapat bermanfaat terhdap anak pidana yang berkonflik dengan hukum. Melalui pelatihan kerja, anak yang berkonflik dengan hukum dapat memiliki pengetahuan dan keterampilan bekerja sehingga ketika selesai menjalani masa pidananya, anak tersebut telah siap untuk bekerja dalamkehidupan yang nyata. ${ }^{5}$ Sebagaimana tujuan sistem peradilan pidana anak untuk mewujudkan kesejahteraan anak sebagai landasan perlindungan hukum bagi anak yang bermasalah dengan hukum ini adalah memberikan keterampilan hingga ia dapat mandiri dan mempunyai kehidupan lebih baik setelah kembalinya menjadi bagian dari masyarakat.

\footnotetext{
${ }^{3}$ Rini Fitriani, 2016, Peranan Penyelenggara Perlindungan Anak Dalam Melindungi dan Memenuhi Hak-Hak Anak, Jurnal Hukum Samudra Keadilan, Volume 2, Nomor 2, Hlm. 251

4 Op.cit

5 Kadek Widiantari, "Perlindungan Hukum Terhadap Anak yang Berkonflik dengan Hukum yang Dijatuhi Pidana Pelatihan Kerja”, Jurnal Masalah-Masalah Hukum, Volume 46 Nomor 4, Oktober 2017, Hlm. 300
} 


\section{Rumusan Masalah}

Rumusan masalah yang diambil pada penelitian ini adalah bagaimana dampak pidana pelatihan kerja untuk anak yang melakukan tindak pidana pencabulan di Balai Perlindungan dan Rehalibitasi Sosial Remaja (BPRSR) Yogyakarta?

\section{Metode Penelitian}

Penelitian ini menggunakan penelitian sosiologi hukum, untuk mengetahui dan menemukan fakta- fakta dan data yang dibutuhkan, kemudian menuju kepada identifikasi masalah yang pada akhirnya menuju pada penyelesaian masalah, melalui teknis analisis data secara kualitatif. Penelitian dilakukan di Balai Perlindungan dan Rehabilitasi Sosial Remaja Yogyakarta dan melakukan wawancara dengan beberapa pihak antara lain, Bambang S. Hadi, (Kasie perlindungan anak pada Balai Perlindungan dan Rehabilitasi Sosial Remaja, Yogyakarta), Sutoyo, Suryani, dan Heri (Pekerja Sosial Fungsional Ahli pada Balai Perlindungan dan Rehabilitasi Sosial Remaja, Yogayakarta), Anak EDM dan Anak FRD (Anak penerima manfaat pada Balai Perlindungan dan Rehalibitasi Sosial Remaja, Yogyakarta).

\section{Hasil Penelitian dan Analisis}

Undang-undang Nomor 11 Tahun 2012 Pasal 2 huruf g memiliki prinsip ataupun asas mengenai pembinaan dan pembimbingan anak. Pembinaan adalah kegiatan untuk meningkatkan kualitas ketakwaan kepada Tuhan yang Maha Esa, intelektual, sikap dan perilaku, pelatihan keterampilan profesional serta kesehatan rohani dan jasmani anak, baik di dalam maupun di luar proses peradilan pidana. Adapun Pembimbingan adalah pemberian tuntutan untuk meningkatkan kualitas ketakwaan kepada Tuhan yang Maha Esa, intelektual, sikap dan perilaku, pelatihan keterampilan profesional, serta kesehatan jasmani dan rohani klien pemasyarakatan.

Tujuan diadakannya peradilan pidana anak tidak hanya mengutamakan penjatuhan pidana saja, tetapi juga perlindungan bagi masa depan anak dari aspek psikologi dengan memberikan pengayoman, bimbingan dan pendidikan. ${ }^{6}$ Tujuan penting dalam peradilan anak adalah memajukan kesejahteraan anak (penghindaran sanksi-sanksi yang sekedar menghukum semata) dan menekankan pada prinsip proposionalitas (tidak hanya didasarkan pada pertimbangan beratnya pelanggaran hukum tetapi juga pada pertimbangan keadaan-keaaan pribadinya, seperti status sosial, keadaan keluarga, kerugian yang ditimbulkan atau faktor lain yang berkaitan dengan keadaan pribadi yang akan mempengaruhi kesepadanan reaksi-reaksinya). ${ }^{7}$

Undang-Undang Nomor 11 Tahun 2012 Tentang Sistem Peradilan Pidana Anak merupakan pengganti dari Undang-Undang Nomor 3 Tahun 1997 tentang Pengadilan Anak. Undang-undang Nomor 3 Tahun 1997 Tentang Pengadilan Anak dinilai sudah tidak sesuai lagi dengan kebutuhan hukum dalam masyarakat dalam memberikan perlindungan khusus kepada anak yang berhadapan dengan hukum. Undang-undang sistem peradilan anak Nomor 11 Tahun 2012 Tentang Sistem Peradilan Pidana Anak lebih menekankan pada perbaikan pada anak pelaku tindak pidana. Perbaikan yang diberikan terhadap anak salah satunya mengenai penerapan pidana pelatihan kerja.

Penjelasan dalam Pasal 78 ayat (1) Undang-undang Nomor 11 Tahun 2012 tentang Sistem Peradilan Pidana Anak menyebutkan bahwa yang dimaksud dengan lembaga yang melaksanakan pelatihan kerja antara lain balai pelatihan kerja, lembaga pendidikan vokasi yang dilaksanakan misalnya oleh kementerian yang menyelenggarakan urusan pemerintahan di bidang Ketenagakerjaan, Pendidikan atau Sosial. Lembaga pelatihan kerja adalah instansi pemerintah, badan hukum atau perorangan yang memenuhi persyaratan untuk menyelenggarakan pelatihan kerja. Contoh dari Balai pelatihan kerja bidang ketegakerjaan adalah LPK Cipta Busana dalam bidang menjahit yang berada di Yogyakarta. Lembaga sosial dibawah naungan Menteri Sosial adalah

\footnotetext{
${ }^{6}$ Maidin Gultom, 2014, Perlindungan Hukum Terhadap Anak dalam Sistem Peradilan Pidana Anak Di Indonesia, Bandung, PT Refika Aditama, Hlm. 93.

7 Setya Wahyudi, 2011, Implementasi Ide Diversi dalam Pembaruan Sistem Peradilan Pidana Anak di Indonesia, Yogyakarta, Genta Publishing, Hlm.35
} 
Lembaga Penyelenggaraan Kesejahteraan Sosial yang selanjutnya disingkat LPKS adalah lembaga atau tempat pelayanan sosial yang melaksanakan penyelenggaraan kesejahteraan sosial bagi Anak.

Balai Perlindungan dan Rehalibitasi Sosial Remaja Yogyakarta menjadi salah satu lembaga pelaksana pelatihan kerja berdasarkan SK Menteri Sosial Nomor 85 Tahun 2017 tentang Lembaga Penyelenggaraan Kesejahteraan Sosial sebagai pelaksana rehabilitasi sosial Anak yang Berhadapan dengan Hukum, Peraturan Menteri Sosial Nomor 30/HUK/2011 Tentang Standar Nasional Pengasuhan Anak untuk Lembaga Kesejahteraan Sosial Anak dan Peraturan Gubernur Daerah Istimewa Yogyakarta Nomor 90 Tahun 2018 tentang Pembentukan, Susunan Organisasi, Uraian Tugas dan Fungsi serta Tata Kerja Unit Pelaksana Teknis Pada Dinas Sosial yang membuat Panti Sosial Bina Remaja (PSBR) Yogyakarta berubah menjadi Balai Perlindungan dan Rehabilitasi Sosial Remaja. Balai Perlindungan dan Rehabilitasi Sosial Remaja Yogyakarta menjadi pelaksana pelatihan kerja berdasarkan putusan pengadilan dan penetapan hakim yang menunjuk Balai Perlindungan dan Rehabilitasi Sosial Remaja Yogyakarta sebagai tempat untuk melaksanakan pidana pelatihan kerja.

Ketentuan Pasal 107 Undang-undang Nomor 11 Tahun 2012 Tentang Sistem Peradilan Pidana Anak mengatur bahwa peraturan perlaksanaan dari Undang-Undang Sistem Peradilan Pidana Anak harus ditetapkan dalam jangka waktu satu tahun sejak Undang-Undang tersebut diberlakukan. Peraturan pelaksana tersebut termasuk peraturan pelaksana mengenai pidana pelatihan kerja yang telah diatur dalam Pasal 71 Ayat (5) bahwa peraturan mengenai cara pelaksaan pidana diatur dalam peraturan pemerintah. Namun, sampai dengan saat ini belum ada Peraturan Pemerintah yang mengatur tentang pelaksaan pelatihan kerja. Belum adanya peraturan pelaksana pidana latihan kerja mengakibatkan tidak adanya bentuk baku dari pelatihan kerja itu sendiri.

Undang-undang Nomor 11 Tahun 2012 Tentang Sistem Peradilan Pidana Anak juga tidak menjelaskan secara eksplisit mengenai bentuk pelatihan kerja yang harus diselenggarakan. Berbeda dengan Undang-undang Pengadilan Anak terdahulu yaitu Undang-Undang Nomor 3 Tahun 1997 yang pada penjelasan pasalnya menjelaskan bahwa wajib latihan kerja dimaksudkan untuk mendidik Anak agar memiliki ketrampilan yang bermanfaat baginya, serta dijelaskan dalam penjelasan Pasal 24 Ayat (1) huruf b bahwa bentuk latihan kerja yang diberikan kepada Anak dapat berupa pemberian ketrampilan mengenai pertukangan, pertanian, perbengkelan, dan tata rias. Sehingga sampai saat ini bentuk implementasi pelatihan kerja masih berdasarkan kebijakan masingmasing lembaga yang ditunjuk sebagai pelaksana pelatihan kerja.

Kegiatan ketrampilan yang disebutkan dalam Undang-undang tentang peradilan anak yang terdahulu sesuai dengan yang dijelaskan dalam Pasal 1 ayat 9 Undang-undang Nomor 13 Tahun 2003 tentang Ketenagakerjaan adalah keseluruhan kegiatan untuk memberi, memperoleh, meningkatkan, serta mengembangkan kompetensi kerja, produktivitas, displin, sikap, dan etos kerja pada tingkat keterampilan dan keahlian tertentu sesuai dengan jenjang dan kualifikasi jabatan atau pekerjaan. Fungsi pelatihan kerja sebagaimana yang disebutkan dalam Pasal 9 Undang-undang Ketenagakerjaan adalah untuk membekali, meningkatkan dan mengembangkan kompetensi kerja guna meningkatkan kemampuan, produktivitas, dan kesejahteraan tenaga kerja. Yang dimaksud dengan peningkatan kesejahteraan disini adalah kesejahteraan bagi tenaga kerja yang diperoleh karena terpenuhinya kompetensi kerja melalui pelatihan kerja.

Bentuk pendidikan dan pelatihan vokasional menurut Peraturan Menteri Sosial Nomor 26 Tahun 2018 Tentang Rehabilitasi Sosial dan Reintegrasi Sosial Bagi Anak Yang Berhadapan Dengan Hukum merupakan bentuk pelatihan untuk penyaluran minat, bakat, dan menyiapkan kemandirian Anak yang Berhadapan dengan Hukum setelah mereka dewasa dalam bentuk keterampilan kerja atau magang kerja. Namun bentuk pendidikan dan pelatihan vokasional yang ada dalam Peraturan Menteri Sosial Nomor 26 Tahun 2018 Tentang Rehabilitasi Sosial dan Reintegrasi Sosial Bagi Anak Yang Berhadapan Dengan Hukum adalah bagian dari rehalibitasi.

Akibat dari ketidakpastian dalam tata cara pelaksanaan dan bentuk penerapan pelatihan kerja. Hal ini menunjukan bahwa sistem peradilan pidana anak tidak dapat bekerja dengan baik dalam menerapkan Pasal 71 ayat (1) huruf c Undang-undang Sistem Peradilan Pidana Anak. Mengatasi hal ini, Balai Perlindungan dan Rehalibitasi Sosial Remaja Yogyakarta sebagai LPKS pelaksana pidana pelatihan kerja memberikan jenis pelatihan kerja berupa membersihkan halaman. Balai Perlindungan dan Rehalibitasi Sosial Remaja Yogyakarta sebagai Lembaga Penyelenggaraan 
Kesejahteraan Sosial (LPKS) pelaksana pidana pelatihan kerja yang ditunjuk berdasarkan amar putusan pengadilan dan putusan pengadilan tidak disebutkan mengenai tata cara pelatihan kerja yang harus dilaksanakan.

Berdasarkan data dari Balai Perlindungan dan Rehalibitasi Sosial Remaja (BPRSR) Daerah Istimewa Yogyakarta dalam rentang waktu 2016 sampai 2019 Anak yang berhadapan dengan hukum yang ada di bawah perlindungan Balai Perlindungan dan Rehalibitasi Sosial Remaja adalah sebanyak:

Tabel 1

Data anak berhadapan dengan hukum $(\mathrm{ABH})$

\begin{tabular}{|l|c|c|c|c|c|c|c|c|c|}
\hline \multirow{2}{*}{} & \multirow{2}{*}{} & Tahun & \multicolumn{2}{|c|}{ Jumlah } & \multicolumn{6}{c|}{ Daerah Asal ABH } \\
\cline { 5 - 10 } & & \multicolumn{2}{|c}{} & $\begin{array}{c}\text { Kota } \\
\text { DIY }\end{array}$ & Sleman & Bantul & G.kidul & Kulonprogo & $\begin{array}{c}\text { Luar } \\
\text { DIY }\end{array}$ \\
\hline 1. & 2016 & 107 & Anak & 27 & 48 & 12 & 7 & 9 & 6 \\
\hline 2. & 2017 & 127 & Anak & 35 & 52 & 15 & 7 & 12 & 6 \\
\hline 3. & 2018 & 142 & Anak & 48 & 51 & 17 & 4 & 6 & 16 \\
\hline 4. & 2019 & 23 & Anak & 4 & 11 & 5 & 1 & 1 & 1 \\
\hline
\end{tabular}

Sumber : Balai Perlindungan dan Rehalibitasi Sosial remaja D.I.Yogyakarta

Data pada tabel di atas menunjukkan bahwa, anak yang berhadapan dengan hukum yang ada dibawah perlindungan Balai Perlindungan dan Rehalibitasi Sosial Remaja Yogyakarta setiap tahun mengalami peningkatan. Anak yang berhadapan dengan hukum tidak hanya berasal dari Yogyakarta saja beberapa anak berasal dari luar Yogyakarta. Peningkatan terjadi pada tahum 2018 sebanyak 142 anak, dengan kota Yogyakarta sebagai terbanyak adalah 48 anak lebih banyak dari sebelumnya yang berjumlah 35 anak. Namun di beberapa kota seperti di Kulon Progo mengalami penurunan di tahun 2018 berjumlah 6 anak dari tahun 2017 berjumlah 12 anak Beberapa anak dalam tabel diatas merupakan pelaku pencabulan.

Berikut data mengenai anak berhadapan dengan hukum Tindak Pidana Pencabulan berdasarkan usia:

Tabel 2

Data mengenai Tindak Pidana Pencabulan yang dilakukan oleh anak:

\begin{tabular}{|c|c|c|c|c|c|c|c|}
\hline \multirow{2}{*}{ No } & \multirow{2}{*}{ Tahun } & \multicolumn{2}{|c|}{ Kasus } & \multicolumn{5}{|c|}{ Usia } \\
\cline { 5 - 8 } & & \multirow{2}{*}{\begin{tabular}{c} 
Pencabulan \\
\cline { 4 - 7 }
\end{tabular}} & & $8-11$ & $12-15$ & $16-19$ & 19 keatas \\
\hline 1 & 2016 & 15 & Anak & - & 23 & 82 & 2 \\
\hline 2 & 2017 & 15 & Anak & - & 26 & 96 & 5 \\
\hline 3 & 2018 & 14 & Anak & 2 & 32 & 103 & 5 \\
\hline 4 & 2019 & 5 & Anak & 1 & 6 & 14 & 2 \\
\hline
\end{tabular}

Sumber : Balai Perlindungan dan Rehalibitasi Sosial Remaja

Data tersebut menunjukkan bahwa, di Balai Perlindungan dan Rehalibitasi Sosial Remaja Yogyakarta dalam rentang waktu kurang dari 4 (empat) tahun terdapat 49 (empat puluh Sembilan) pidana pencabulan. Pidana pencabulan oleh anak yang ada di Balai Perlindungan dan Rehalibitasi Sosial Remaja paling banyak terjadi pada usia 16 (enam belas) tahun sampai 19 (sembilan belas) tahun. Dari kasus pencabulan diatas hanya beberapa yang mendapat putusan pidana pelatihan kerja. Berikut data mengenai anak kasus pencabulan yang melaksanakan pelatihan kerja: 
Vol. 1, No. 2 Juli 2020

P-ISSN: 2745-7192 E-ISSN: 2745-7184
Pusat Kajian Hukum Pidana dan Kriminologi

Fakultas Hukum Universitas Muhammadiyah Yogyakarta

Jalan Brawijaya, Kasihan, Bantul, Yogyakarta 55183

Telp. (0274)387656 Ext. 472

E-mail: ijclc@umy.university

Data Mengenai Pidana Pelatihan Kerja Anak Pencabulan

\begin{tabular}{|l|l|c|}
\hline No & Tahun & Pelatihan kerja Anak Pidana Pencabulan \\
\hline 1 & 2016 & 1 Anak \\
\hline 2 & 2017 & 5 Anak \\
\hline 3 & 2018 & 5 Anak \\
\hline
\end{tabular}

Sumber : Balai Perlindungan dan Rehalibitasi Sosial Remaja DIY

Dari tabel diatas pelatihan kerja yang dilakukan anak pencabulan pada rentang waktu 3 tahun berjumlah 11 anak. Masing-masing anak Pidana Pelatihan Kerja mendapatkan lama pelaksanaan pelatihan kerja yang berbeda sesuai dengan putusan pengadilan. Peneliti melakukan penelitian kepada anak yang menjalankan Pidana Pelatihan Kerja yakni anak EDM dan anak FRD. ${ }^{8}$ Bentuk Pelatihan Kerja yang dilakukan anak EDM dan FRD adalah membersihkan masjid. Lamanya Pelaksanaan Pidana Pelatihan Kerja yang dilakukan anak adalah sebagai berikut:

Tabel 4

Pidana pelatihan kerja anak pencabulan

\begin{tabular}{|l|l|l|l|}
\hline No. & Nama & Lama pelatihan kerja & pelaksanaan \\
\hline 1. & EDM & 6 bulan & 2 bulan \\
\hline 2. & FRD & 3 bulan & 2 bulan \\
\hline
\end{tabular}

Sumber : Balai Perlindungan dan Rehalibitasi Sosial Remaja DIY

Berdasarkan tabel diatas, anak EDM dengan lama pelatihan kerja 6 bulan dan anak FRD dengan lama pelatihan kerja 3 (tiga) bulan. Pelaksanaan pelatihan kerja anak dalam 1 (satu) hari di Balai Perlindungan dan Rehalibitasi Sosial Remaja Yogyakarta adalah 2 (dua) jam. Anak EDM melaksanakan pelatihan kerja di waktu sore setelah melaksanakan sholat ashar. Pelatihan kerja untuk Anak EDM adalah membersihkan masjid, tempat wudhu dan halaman masjid. Pelaksanaan pelatihan kerja anak FRD sama dengan anak EDM, namun pelaksanaannya siang setelah sholat dzuhur.

Berikut catatan anak EDM tentang pelakanaan pelatihan kerja yang dilakukan anak tanggal 8 mei sampai 16 mei 2019 sebagai berikut:

Tabel 5

Jadwal anak EDM tanggal 8 Mei hingga 16 Mei 2019

\begin{tabular}{|l|l|l|}
\hline No & Tanggal & Uraian kegiatan \\
\hline 1 & 08 mei 2019 & Bersih masjid dan halaman masjid sehabis ashar \\
\hline 2 & 09 mei 2019 & Bersih masjid dan lantai aula atas \\
\hline 3 & 10 mei 2019 & Bersih masjid \\
\hline 4 & 11 mei 2019 & Bersih halaman masjid \\
\hline 5 & 12 mei 2019 & Bersih halaman masjid \\
\hline 6 & 13 mei 2019 & Bersih halaman masjid dan ngepel halaman masjid \\
\hline 7 & 14 mei 2019 & Ngepel masjid, bersihkan wc dan tempat wudhu \\
\hline 8 & 15 mei 2019 & Bersih halaman masjid \\
\hline 9 & 16 mei 2019 & Ngepel masjid luar dan dalam \\
\hline
\end{tabular}

Sumber : Anak EDM pada Balai perlindungan dan Rehalibitasi Sosial Remaja

\footnotetext{
${ }^{8}$ Hasil wawancara dengan ibuk Suryani. Selaku Pekerja Sosial. Jumat 17 mei 2019. Balai Perlindungan dan Rehalibitasi Sosial Remaja Yogyakarta.
} 
Kegiatan diatas dilakukan anak EDM selama 2 bulan dengan pelatihan kerja membersihkan masjid sesuai dengan yang telah disepakati antara pekerja sosial dan anak. Anak EDM hanya mencatat kegiatannya pertanggal 8 mei sampai 16 mei 2019 Sedangkan anak FRD tidak memiliki catatan kegiatan seperti anak EDM. ${ }^{9}$ Pelatihan kerja yang dilakukan anak adalah pelatihan untuk mengerjakan pekerjaan tertentu seperti membersihan halaman dan masjid. Pelatihan kerja ini dimaksudkan untuk memberikan tanggung jawab untuk melatih anak bekerja dan anak tetap mendapatkan rehalibitasi selama berada dalam perlindungan balai Perlindungan dan Rehalibitasi Sosial Remaja Yogyakarta. Berikut ini kegiatan yang dilakukan anak selama berada di Balai Perlindungan dan Rehalibitasi Sosial Remaja Yogyakarta seperti:

Tabel 6

Jadwal Kegiatan Penerima Manfaat Balai Perlindungan dan Rehalibitasi Sosial Remaja

\begin{tabular}{|c|c|c|c|c|c|}
\hline \multirow[t]{2}{*}{ No } & \multirow[t]{2}{*}{ Jam } & \multicolumn{4}{|c|}{ Hari } \\
\hline & & Senin & Selasa & Rabu & Kamis \\
\hline 1 & $04.30-05.15$ & Sholat shubuh & $\begin{array}{l}\text { Kedisiplinan } \\
\text { pagi }\end{array}$ & Sholat ahubuh & disiplin pagi \\
\hline 2 & $05.15-06.00$ & $\begin{array}{l}\text { Kegiatan } \\
\text { Pribadi }\end{array}$ & $\begin{array}{l}\text { Kedisiplinan } \\
\text { pagi }\end{array}$ & Kegiatan pribadi & disiplin pagi \\
\hline 3 & $06.00-07.00$ & Bersih Asrama & Bersih Asrama & Bersih Asrama & Bersih Asrama \\
\hline 4 & $07.00-07.30$ & Makan pagi & Makan pagi & Makan pagi & Makan pagi \\
\hline 5 & $07.30-09.00$ & $\begin{array}{l}\text { pimpinan/peks } \\
\text { os }\end{array}$ & $\begin{array}{l}\text { pimpinan/peks } \\
\text { os }\end{array}$ & $\begin{array}{l}\text { pimpinan/pekso } \\
\text { S }\end{array}$ & $\begin{array}{l}\text { Bimbingan } \\
\text { agama }\end{array}$ \\
\hline 6 & 09.00-11.15 & Ketrampilan & Ketrampilan & Ketrampilan & Ketrampilan \\
\hline 7 & $11.15-13.00$ & Ishoma & Ishoma & Ishoma & Ishoma \\
\hline 8 & $13.00-14.30$ & Psikolog & $\begin{array}{l}\text { Etika budi } \\
\text { pekerti }\end{array}$ & $\begin{array}{l}\text { Pembinaan } \\
\text { hukum }\end{array}$ & Karawitan/band \\
\hline 9 & $14.30-15.30$ & Ishoma & Ishoma & Ishoma & Ishoma \\
\hline 10 & $15.30-16.15$ & Disiplin sore & Olahraga & $\begin{array}{l}\text { Bersih } \\
\text { lingkungan }\end{array}$ & Pertanian \\
\hline 11 & $16.15-17.00$ & Disiplin sore & Olahraga & $\begin{array}{l}\text { Bersih } \\
\text { lingkungan }\end{array}$ & Pertanian \\
\hline 12 & $17.00-18.00$ & Bersih asrama & Bersih asrama & Bersih asrama & Bersih asrama \\
\hline 13 & $18.00-18.15$ & Sholat magrib & Sholat magrib & Sholat magrib & Sholat magrib \\
\hline 14 & $18.15-19.00$ & $\begin{array}{l}\text { Bimbingan } \\
\text { agama }\end{array}$ & $\begin{array}{l}\text { Kegiatan } \\
\text { pribadi }\end{array}$ & $\begin{array}{l}\text { Bimbingan } \\
\text { agama }\end{array}$ & Kegiatan pribadi \\
\hline 15 & $19.00-19.45$ & $\begin{array}{l}\text { Bimbingan } \\
\text { agama }\end{array}$ & Sholat isya & $\begin{array}{l}\text { Bimbangan } \\
\text { agama }\end{array}$ & Sholat Isya \\
\hline 16 & $19.45-20.30$ & Makan Malam & Makan Malam & Makan Malam & Makan Malam \\
\hline 17 & $20.30-21.00$ & $\begin{array}{l}\text { Kegiatan } \\
\text { Pribadi }\end{array}$ & $\begin{array}{l}\text { Kegiatan } \\
\text { pribadi }\end{array}$ & Kegiatan Pribadi & Kegiatan Pribadi \\
\hline 18 & $21.00-21.15$ & Apel Malam & Apel Malam & Apel Malam & Apel Malam \\
\hline 19 & $21.15-05.00$ & $\begin{array}{l}\text { Istirahat } \\
\text { Malam }\end{array}$ & $\begin{array}{l}\text { Istirahat } \\
\text { Malam }\end{array}$ & Istirahat Malam & Istirahat Malam \\
\hline
\end{tabular}

\footnotetext{
${ }^{9}$ Hasil wawancara dengan anak EDM sebagai anak yang berhadapan dengan hukum. pada tanggal 17 mei 2019 di Balai Perlindungan dan Rehalibitasi Sosial Remaja Yogyakarta.
} 


\begin{tabular}{|c|c|c|c|c|}
\hline \multirow[t]{2}{*}{ No } & \multirow[t]{2}{*}{ Jam } & \multicolumn{3}{|c|}{ Hari } \\
\hline & & Jumat & sabtu & Minggu \\
\hline 1 & $04.30-05.15$ & Sholat shubuh & Kedisiplinan pagi & Sholat shubuh \\
\hline 2 & $05.15-06.00$ & Kegiatan pribadi & Kediseiplinan pagi & Kegiatan pribadi \\
\hline 3 & $06.00-07.00$ & Bersih Asrama & Kebersihan asrama & Bersih asrama \\
\hline 4 & $07.00-07.30$ & Makan pagi & Makan pagi & Makan pagi \\
\hline 5 & $07.30-09.00$ & Senam & Dinamika kelompok & Kerja bakti \\
\hline 6 & 09.00-11.15 & $\begin{array}{l}\text { Bimbingan } \\
\text { Kesehatan }\end{array}$ & ketrampilan & Cek kesehata \\
\hline 7 & $11.15-13.00$ & $\begin{array}{l}\text { bimbingan } \\
\text { Agama }\end{array}$ & Ishoma & Ishoma \\
\hline 8 & $13.00-14.30$ & Kegiatan pribadi & Sablon & Sunday Activity \\
\hline 9 & $14.30-15.30$ & Ishoma & Ishoma & Ishoma \\
\hline 10 & $15.30-16.15$ & Kegiatan pribadi & Kegiatan Pribadi & Kegiatan pribadi \\
\hline 11 & $16.15-17.00$ & Kegiatan pribadi & Kegiatan pribadi & Kegiatan pribadi \\
\hline 12 & $17.00-18.00$ & Bersih asrama & Bersih asrama & Bersih asrama \\
\hline 13 & $18.00-18.15$ & Sholat magrib & Sholat magrib & Sholat magrib \\
\hline 14 & $18.15-19.00$ & $\begin{array}{l}\text { Bimbingan } \\
\text { agama }\end{array}$ & Bimbingan agama & Kegiatan pribadi \\
\hline 15 & $19.00-19.45$ & $\begin{array}{l}\text { Bimbingan } \\
\text { agama }\end{array}$ & Bimbingan agama & Sholat Isya \\
\hline 16 & $19.45-20.30$ & Makan Malam & Makan Malam & Makan Malam \\
\hline 17 & $20.30-21.00$ & Kegiatan Pribadi & Kegiatan Pribadi & Kegiatan pribadi \\
\hline 18 & $21.00-21.15$ & Apel Malam & Apel Malam & Apel Malam \\
\hline 19 & $21.15-05.00$ & Istirahat Malam & Istirahat Malam & Istirahat Malam \\
\hline
\end{tabular}

Sumber : Balai Perlindungan dan Rehalibitasi Sosial remaja D.I.Yogyakarta

Berdasarkan tabel diatas, kegiatan yang dilakukan oleh anak tersebut adalah kegiatan dari rehalibitasi yang ada di Balai Perlindungan dan Rehalibitasi Sosial Remaja Yogyakarta. ${ }^{10}$ Bimbingan psikologi yang dilakukan oleh seorang psikolog dimana anak akan mendapatkan bimbingan pribadi maupun kolektif. Bimbingan ini bertujuan untuk pengembangan aspek kognitif atau pengetahuan, afektif atau sikap, konatif atau bentuk tingkah laku, dan sosial yang bertujuan untuk terjadinya perubahan sikap dan perilaku Anak yang berhadapan dengan hukum ke arah yang adaptif. Bimbingan hukum dimaksudkan untuk memberikan pengarahan, pengetahuan dan pembelajaran mengenai hukum sehingga anak menjadi lebih mengerti dan mengetahui kesalahannya dan tidak mengulangi perbuatan tersebut. Bimbingan hukum yang dibimbing langsung oleh pihak kepolisian.

Terapi mental dan spiritual merupakan kegiatan pemahaman pengetahuan dasar keagamanan, etika kepribadian, dan kedisiplinan yang ditujukan untuk memperkuat sikap/karakter dan nilai spiritual yang dianut Anak yang melakukan tindak pidana. Terapi mental dan spiritual dilaksanakan dalam bentuk ceramah keagamaan, bimbingan keagamaan, pelaksanaan ibadah, pembentukan karakter, pemahaman nilai budaya, dan disiplin yang dilaksanakan secara individu atau kelompok. Pelatihan vokasional merupakan bentuk pelatihan untuk penyaluran minat, bakat,

10 Hasil wawancara dengan bapak Heri. Selaku Pekerja Sosial. Jumat 17 mei 2019. Balai Perlindungan dan Rehalibitasi Sosial Remaja Yogyakarta. 
dan menyiapkan kemandirian anak dalam bentuk keterampilan kerja atau magang kerja seperti bengkel, las, pertukangan,salon dan menjahit.

Dalam pelaksanaan pelatihan kerja juga terdapat peran dari pekerja sosial yang bekerja mendampingi anak selama anak menjalani pidana pelatihan kerja. pekerja sosial dalam Undangundang Nomor 11 Tahun 2009 Tentang Kesejahteraan Sosial bahwa Seseorang yang bekerja, baik di lembaga pemerintah maupun swasta yang memiliki kompetensi dan profesi pekerjaan sosial, dan kepedulian dalam pekerjaan sosial yang diperoleh melalui pendidikan, pelatihan, dan/atau pengalaman praktek pekerjaan sosial untuk melaksanakan tugas-tugas pelayanan dan penanganan masalah sosial.

Pekerja Sosial adalah sebagai pendamping anak dalam menghadapi masalah yang sedang dihadapi, Pekerja Sosial berperan langsung dalam proses pembinaan anak dengan melakukan pembinaan langsung terhadap anak yang memiliki masalah dan membantu serta mendampingi mereka mulai dari mereka masuk ke balai, selama proses penyelesaian masalah, sampai masalah tersebut selesai ditangani. Pekerja Sosial memliki peran secara langsung dalam pembinaan anak seperti melakukan pendampingan. Selain itu Pekerja Sosial juga berperan sebagai orang tua mereka selama mereka tinggal di Balai Perlindungan dan Rehalibitasi Sosial Remaja Yogyakarta. ${ }^{11}$

Anak yang melaksanakan pidana pelatihan kerja di Balai Perlindungan dan Rehalibitasi Sosial Remaja Yogyakarta diberikan rehalibitasi seperti yang dijabarkan diatas, baik dari aspek spikologi, agama, hukum dan ketrampilan. Dalam pelaksanaan pelatihan kerja terdapat faktor pendukung dan faktor penghambat, beberapa faktor pendukung pelatihan kerja antara lain:

a. Anak yang melaksankan pidana pelatihan kerja juga diberikan rehalibitasi.

b. Adanya kemauan anak untuk berubah kearah yang lebih baik.

c. Waktu pelaksanaan pelatihan kerja yang fleksibel.

Selain faktor pendukung, ada juga faktor penghambat selama pelaksanaan pelatihan kerja, antara lain:

1) Kurangnya Dukungan keluarga.

2) Belum tercukupinya sarana untuk pelatihan kerja.

3) Belum ada program khusus untuk anak yang melaksanakan pidana pelatihan kerja.

Dari hasil wawancara di atas, dapat disimpulkan bahwa bentuk pidana pelatihan kerja yang diterapkan di Balai Perlindungan dan Rehalibitasi Sosial Remaja Yogyakarta untuk anak EDM dan FRD adalah membersihkan masjid, tempat wudhu dan halaman masjid. Namun pelatihan kerja yang dimaksudkan Undang-undang ketegakerjaan bahwa pelatihan kerja adalah kegiatan untuk memberi, memperoleh, meningkatkan, serta mengembangkan kompetensi kerja, produktivitas, displin, sikap, dan etos kerja pada tingkat keterampilan dan keahlian tertentu sesuai dengan jenjang dan kualifikasi jabatan atau pekerjaan. BPRSR menyediakan bimibngan ketrampilan seperti las, bengkel, pertukangan, salon untuk mengembangkan bakat dan minat anak. Apabila ini dijadikan sebagai pelatihan kerja akan jauh lebih bermanfaat dibandingkan membersihkan masjid. Meskipun belum ada aturan pelaksana yang mengatur tata cara pelaksanaan pelatihan kerja dan dalam putusan pengadilan anak tidak di cantumkan bentuk pelatihan kerjanya, Balai Perlindungan dan Rehalibitasi Sosial Remaja Yogyakarta dapat memberikan pelatihan ketrampilan untuk anak. Selain anak juga mendapat pelatihan ketrampilan anak akan juga diberikan rehalibitasi untuk pembinaan mental anak.

\section{Simpulan dan saran}

\section{A. Simpulan}

Pelaksanaan pidana pelatihan kerja yang ditetapkan dalam Undang-undang Nomor 11 Tahun 2012 tentang SPPA tidak menjelaskan secara eksplisit mengenai bentuk pelatihan kerja yang harus diselenggarakan. Berbeda dengan Undang-undang Pengadilan Anak terdahulu yaitu

\footnotetext{
${ }^{11}$ Hasil wawancara dengan narasumber. Drs.Bambang S Hadi. Selaku kepala seksi perlindungan. Rabu 30 januari 2019. Balai Perlindungan dan Rehalibitasi Sosial Remaja.
} 
Undang-Undang Nomor 3 Tahun 1997 yang pada penjelasan pasalnya menjelaskan bahwa wajib latihan kerja dimaksudkan untuk mendidik Anak agar memiliki ketrampilan yang bermanfaat baginya, bentuk latihan kerja yang diberikan kepada Anak dapat berupa pemberian ketrampilan mengenai pertukangan, pertanian, perbengkelan, dan tata rias. Dengan tidak adanya penjelasan mengenai tata cara pelaksanaan pelatihan kerja, bentuk implementasi pelatihan kerja masih berdasarkan kebijakan masing-masing lembaga yang ditunjuk sebagai pelaksana pelatihan kerja. Balai Perlindungan dan Rehabilitasi Sosial Remaja Yogyakarta menjadi pelaksana pelatihan kerja berdasarkan putusan pengadilan dan penetapan hakim yang ditunjuk sebagai tempat untuk melaksanakan pidana pelatihan kerja menerapkan pelaksanaan berupa membersihkan masjid, tempat wudhu dan halaman masjid. Pelaksaannya dilaksanakan sesuai jadwal yang telah disepakati oleh Pekerja Sosial dan Anak dengan waktu pelaksanaan 2 (dua) jam dalam sehari. Pelaksanaan pelatihan kerja juga diikuti dengan kegiatan rehalibitasi, karena Balai Perlindungan dan Rehalibitasi Sosial Remaja Yogyakarta bukan hanya sebagai pelaksana pelatihan kerja namun juga sebagai balai rehalibitasi untuk anak, dampak pelaksanaannya tidak dapat dinilai atau tidak berdampak sesuai dengan bentuk tindak pidananya.

\section{B. Saran} berikut :

Berdasarkan kesimpulan dari pembahasan diatas penulis memberikan saran sebagai

1. Kepada Lembaga Negara yang berwenang membentuk perundang-undangan untuk segera mengeluarkan Undang-undang terkait dengan Pelaksanaan Pidana Pelatihan kerja yang sesuai dengan Undang-undang nomor 11 tahun 2012 tentang sistem peradilan pidana anak.

2. Kepada Pengadilan yang menangani perkara anak untuk memberikan putusan tentang bentuk pelatihan kerja yang akan dilaksanakan oleh anak yang melakukan tindak pidana.

3. Kepada Balai Perlindungan dan rehalibitasi sosial remaja yogyakarta untuk mengakaji lebih jauh tentang pelatihan kerja, pendidikan vokasional dan pelatihan ketrampilan. Supaya, dalam melaksanaan pelatihan kerja anak mendapat manfaat dari pelaksaan tersebut.

\section{DAFTAR PUSTAKA}

\section{Buku}

Amirrudin, 2006, Pengantar Metode Penelitian Hukum, Raja Grafindo Persada, Jakarta.

Bambang Waluyo, 2002, Penelitian Hukum dalam Praktek. Sinar Grafika, Jakarta.

Bahder Johan Nasution, 2008, Metode Penelitian Ilmu Hukum, Bandar Maju, Bandung,

Maidin Gultom, 2008, Perlindungan Hukum Terhadap Anak, Refika Aditama,Bandung.

Maidin Gultom, 2014, Perlindungan Hukum Terhadap Anak dalam Sistem Peradilan Pidana Anak Di Indonesia, PT Refika Aditama, Bandung.

Peter Mahmud Marzuki, 1983, Metodologi Riset, Hanindita Offset, Yogyakarta.

Setya Wahyudi, 2011, Implementasi Ide Diversi dalam Pembaruan Sistem Peradilan Pidana Anak di Indonesia, Genta Publishing, Yogyakarta.

Suharsimi Arikunto, 2002, Prosedur Penelitian Suatu Pendekatan Praktek, Rineka Cipta, Jakarta.

Soerjono Soekanto, 1986, Pengantar Penelitian Hukum, Universitas Indonesia, Jakarta.

\section{Jurnal}

Kadek Widiantari, "Perlindungan Hukum Terhadap Anak yang Berkonflik dengan Hukum yang Dijatuhi Pidana Pelatihan Kerja", Jurnal Masalah - Masalah Hukum, Volume 46 Nomor 4 (2017).

Rini Fitriani, inPeranan Penyelenggara Perlindungan Anak Dalam Melindungi dan Memenuhi Hak-Hak Anak, Jurnal Hukum Samudra Keadilan,Volume 2, Nomor 2 (2016). 


Indonesian Joumal of Criminal Law and Criminology $\begin{aligned} & \text { Vol. 1, No. } 2 \\ & \text { Juli } 2020\end{aligned} \begin{aligned} & \begin{array}{l}\text { Pusat Kajian Hukum Pidana dan Kriminologi } \\ \text { Fakultas Hukum Universitas Muhammadiyah Yogyakarta } \\ \text { Jalan Brawijaya, Kasihan, Bantul, Yogyakarta 55183 } \\ \text { Telp. (0274)387656 Ext. 472 }\end{array} \\ & \text { E-ISSN: 2745-7184 }\end{aligned}$

\section{Perundang-undangan}

Undang-undang Nomor 13 Tahun 2003 Tenftang Ketenagakerjaan

Undang-undang Nomor 35 Tahun 2014 Tentang perlindungan anak

Undang-undang Nomor 11 Tahun 2012 Tentang Sistem Peradilan Pidana Anak

Undang-undang Nomor 12 Tahun 1995 Tentang Pemasyarakatan 